\title{
Procesy starzenia się w środowisku wielkomiejskim w Polsce na początku XXI wieku. Wymiar demograficzny i społeczny*
}

\section{Streszczenie}

W artykule przedstawiono podstawowe założenia socjologicznej analizy środowiska wielkomiejskiego w kontekście starzenia się populacji miejskiej. Omówiono główne koncepcje wypracowane na gruncie gerontologii społecznej oraz zaprezentowano społeczną perspektywę procesów starzenia się populacji miejskiej. Wykorzystując analizę danych zastanych, przedstawiono główne trendy demograficzne obserwowane współcześnie w polskich miastach, opisując wskaźniki wykorzystywane w analizie procesów starzenia się populacji. Wnioski wynikające z analizy wskazują, że z jednej strony malejąca liczba urodzeń i ruchy migracyjne powodować będą „,kurczenie się miast”, z drugiej zaś zmiany w sektorze zatrudnienia i rozwój infrastruktury przyczyniać się będą do „rozlewania się miast”. W efekcie miasto będzie stawać się środowiskiem życia, w którym osoby starsze będą stanowić coraz liczniejszą grupę mieszkańców.

Słowa kluczowe: starzenie się, gerontologia społeczna, miasto, socjologia starości. Klasyfikacja JEL: J11.

Anna Urbaniak, Uniwersytet Ekonomiczny w Krakowie, Wydział Gospodarki i Administracji Publicznej, Katedra Socjologii, ul. Rakowicka 27, 31-510 Kraków, e-mail: anna.urbaniak@uek. krakow.pl

* Artykuł powstał w ramach badań statutowych Katedry Socjologii finansowanych ze środków własnych przez Uniwersytet Ekonomiczny w Krakowie. 


\section{Wprowadzenie}

Celem niniejszego opracowania jest przedstawienie procesu starzenia się polskich miast i wskazanie jego możliwych konsekwencji w wymiarze demograficznym i społecznym. Problematyką starzenia się środowisk miejskich zajmują się w różnym zakresie demografowie [Wierzchosławski 1999], geografowie [Grzelak-Kostulska 2001, Długosz i Kurek 2005], socjologowie [Szukalski 2010], architekci [Labus 2013] i gerontolodzy [Wnuk i in. 2008]. W polskiej literaturze przedmiotu można znaleźć wiele prac prezentujących przestrzenne zróżnicowanie poziomu starości demograficznej i dynamiki procesu starzenia się ludności w Polsce, Europie i na świecie. Tematem starzenia się w ujęciu regionalnym w Polsce zajmowali się liczni badacze [Bielecka 1976, Artysiewicz 1977, Gordecka 1980, Niekrasz 1980, Długosz i Rachwał 1998, Frąckiewicz 2004, Długosz i Kurek 2005, Kurek 2008, Wolańska 2013]. Rzadziej natomiast poruszana była tematyka dotycząca procesu starzenia się ludności dużych miast. Należy wymienić tu opracowania W. Obraniaka [1992, 2006] oraz Z. Długosza i S. Kurka [1997]. W ujęciu historycznym zmiany struktury wieku ludności Polski w powiatach od $1931 \mathrm{r}$. przedstawione zostały w monografii A. Gawryszewskiego [2005]. W niniejszym artykule proces starzenia się omówiony zostanie z perspektywy demograficzno-społecznej.

\section{Dynamika procesów starzenia się ludności polskich miast}

Według niektórych autorów początki starzenia się ludności polskich miast wynikające ze zmian w procesach reprodukcji można datować na $1880 \mathrm{r}$. [Szukalski 2010, s. 108]. Skala i tempo tego zjawiska zaczęły wyraźnie zmieniać się w latach 90. XX w. (rys. 1). Szczególnie wyraźny wzrost liczby ludności z tej grupy miał miejsce od $2006 \mathrm{r}$. W odniesieniu do malejącej liczby ludności całego kraju należy rozważać różnicę nie w liczbach bezwzględnych, ale w udziale procentowym, jaki najstarsza grupa ludności stanowi w liczbie ludności ogółem, czyli odwołać się do wartości wskaźnika starości demograficznej ${ }^{1}$.

Zestawiając zaprezentowane na rys. 1 wartości z 1995 r., w którym udział ten wynosił 15,87\%, z 2016 r., w którym wyniósł już 23,6\%, widać bardzo wyraźny wzrost. Zmiany udziału liczby ludności w wieku 60 lat i więcej w Polsce w latach 1995-2016 przedstawiono na rys. 2.

\footnotetext{
${ }^{1}$ Wskaźnik ten konstruuje się na podstawie liczby ludności, która przekroczy umowny próg starości. Najczęściej przyjmuje się wiek 60 lub 65 lat, co często jest krytykowane. Stąd w ostatnich latach podejmowane są liczne próby skonstruowania bardziej kompleksowych i adekwatnych miar do analizy procesów starzenia się [Kurek 2008, Wolańska 2013].
} 


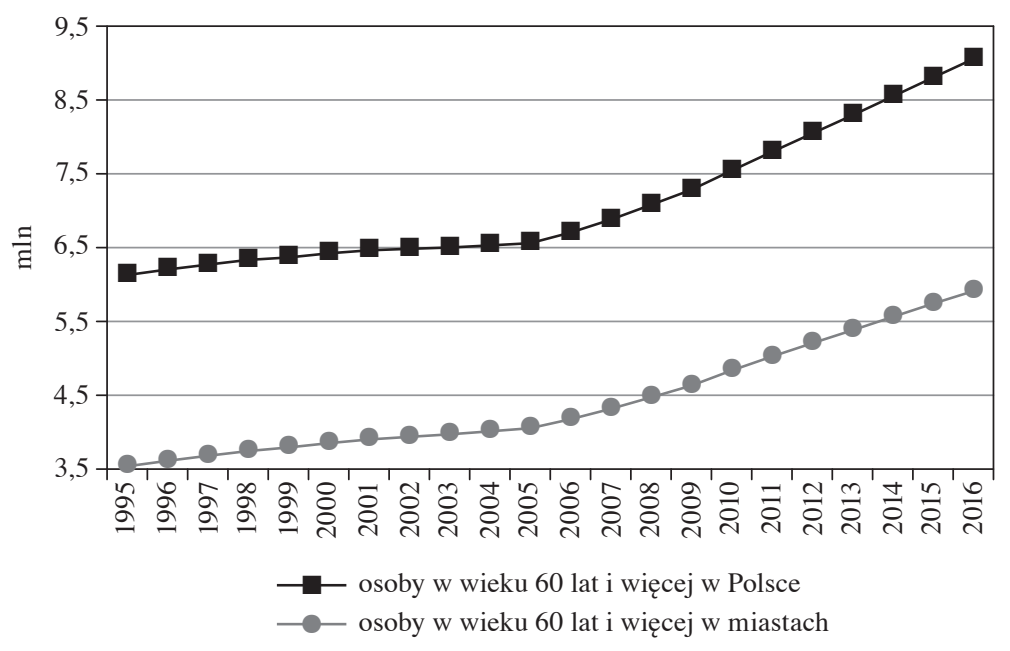

Rys. 1. Dynamika przyrostu ludności w wieku 60 lat i więcej w latach 1995-2016 Źródło: opracowanie własne na podstawie: Bank Danych Lokalnych, GUS, www.stat.gov.pl/bdl (data dostępu: 18.03.2017).

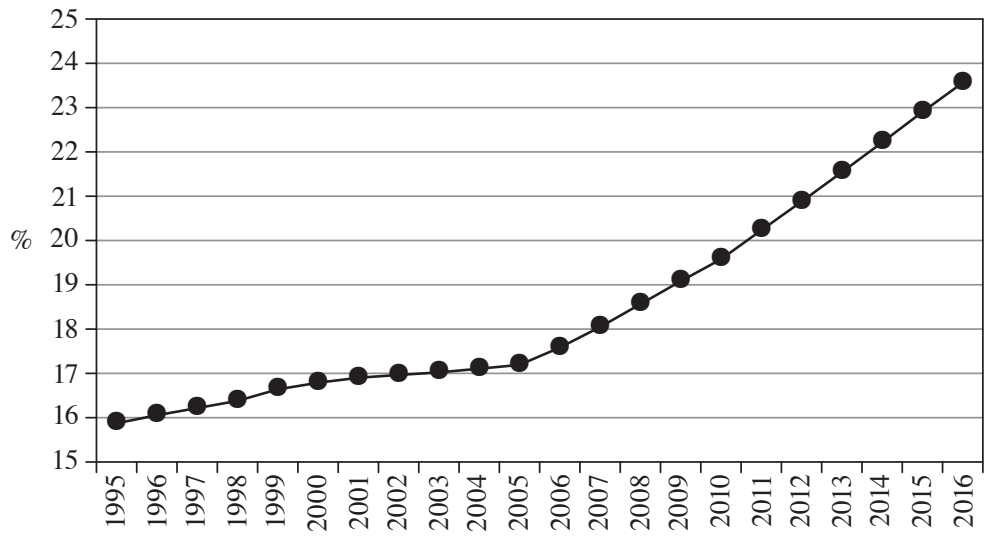

Rys. 2. Dynamika udziału ludności w wieku 60 lat i więcej w liczbie ludności Polski w latach 1995-2016

Źródło: opracowanie własne na podstawie: Bank Danych Lokalnych, GUS, www.stat.gov.pl/bdl (data dostępu: 18.03.2017). 
Warto także zwrócić uwagę na systematycznie wzrastającą liczbę osób starszych mieszkających w miastach. Wśród osób w wieku 60 lat i więcej w 2016 r. w miastach żyło $65,27 \%$, podczas gdy w 1995 r. było to $57,72 \%$.

Na proces starzenia się polskich miast największy wpływ mają dwa jednocześnie zachodzące procesy: wydłużanie się życia ludzkiego z jednej strony i malejący przyrost naturalny z drugiej. Według prognozy demograficznej z 2003 r. [Prognoza ludności... 2004] do 2030 r. liczba osób po 60. roku życia może w Polsce wzrosnąć do $10 \mathrm{mln}$, co stanowić będzie $29 \%$ ogółu ludności, przy czym w miastach - do 6,6 mln, co stanowić będzie 32,5\% ludności miast. Według prognozy na lata 2008-2035 liczba osób po 60. roku życia może wzrosnąć w tym okresie do 10,8 mln (30\% ogółu ludności), a w miastach - do 6,5 mln (31\% ogółu ludności miast) [Prognoza ludności... 2009, s. 209, 156-158, 173-175]. Procesom tym towarzyszyć będzie tzw. podwójne starzenie się, czyli szybki wzrost w populacji seniorów udziału grup „starszych starych” i „długowiecznych”, co będzie prowadzić do większego zróżnicowania nie tylko kategorii społecznej ludzi starych, ale też potrzeb i metod rozwiązywania ich problemów [Szukalski 2009, s. 23].

Miasta, które będą się starzeć i „kurczyć”, będą mieć ograniczone szanse na wykorzystanie kreatywności mieszkańców, stworzenie atrakcyjnych obszarów gospodarczych oraz będą zagrożone rozkładem struktury części usług i dostępu do nich [Katsarova 2008].

Według prognozy demograficznej Eurostatu z 2010 r. dla 27 krajów europejskich, w której przyjęto założenie o konwergencji procesów demograficznych w krajach Unii Europejskiej wraz z niwelowaniem istniejących między nimi różnic społeczno-ekonomicznych i kulturowych, udział osób w wieku powyżej 60 lat będzie wynosił średnio 30,4\% w 2030 r., a w 2060 r. 35,2\%. W Polsce natomiast odpowiednio $27,9 \%$ i 40,3\%. Średni wiek mieszkańców krajów Unii wzrośnie w 2030 r. do 44,4 roku, a w 2060 r. do 47,2 roku, w Polsce zaś odpowiednio do 45,3 roku i 51,2 roku. Wskaźnik obciążenia ludności w wieku produkcyjnym ludnością w wieku poprodukcyjnym, który wyraża się stosunkiem liczby osób w wieku 65 lat i więcej do liczby osób w wieku 15-64 lat, będzie systematycznie wzrastał w krajach Unii - do 36,4\% w 2030 r. i 52,4\% 30 lat później. W Polsce będzie to odpowiednio 35,2\% i 64,6\%. Według tej prognozy ludność Polski zmniejszy się z 38,1 mln osób w 2010 r. do 37,5 mln w 2030 r. i 32,7 mln w 2060 r. Opóźniony i szybszy proces starzenia się populacji Polski sprawi, że jej sytuacja demograficzna będzie kształtować się relatywnie gorzej niż w większości państw Unii Europejskiej (za: [Klimczuk 2012, s. 46]).

Warto podkreślić, że proces starzenia się miast w Polsce ma zróżnicowany przebieg i dynamikę, na co zwracają uwagę zarówno demografowie, jak i geografowie czy socjologowie [Wierzchosławski 1999, Długosz i Kurek 2005, Kurek 2008, Szukalski 2010]. Biorąc pod uwagę udział osób w wieku 60 lat i więcej 
w liczbie ludności ogółem, możliwe jest wskazanie grupy najmłodszych miast; są to: Rybnik, Rzeszów, Białystok, Tychy, Olsztyn, Ruda Śląska, Elbląg, Radom i Gorzów Wielkopolski. W grupie najstarszych miast znajdują się Gdynia, Katowice i Łódź. Jak można zauważyć, w poszczególnych grupach znalazły się miasta zarówno bardzo duże, jak i średnie, z różnych regionów Polski.

\section{Analiza porównawcza procesów starzenia się w wybranych największych miastach Polski}

Spośród największych miast Polski, liczących powyżej 400 tys. mieszkańców, najbardziej zbliżone pod względem udziału ludności w wieku 60 lat i więcej w ogólnej liczbie ludności są: Wrocław, Poznań, Gdańsk i Warszawa (rys. 3). Udział ludności z tej grupy wieku wynosił w nich w 2016 r. ponad 26,5\%. Łódź na tym tle jest wyraźnie starsza - wartość tego wskaźnika utrzymywała się na poziomie powyżej 30\%, z kolei dla Krakowa wartość tego wskaźnika była niższa niż $26 \%$.

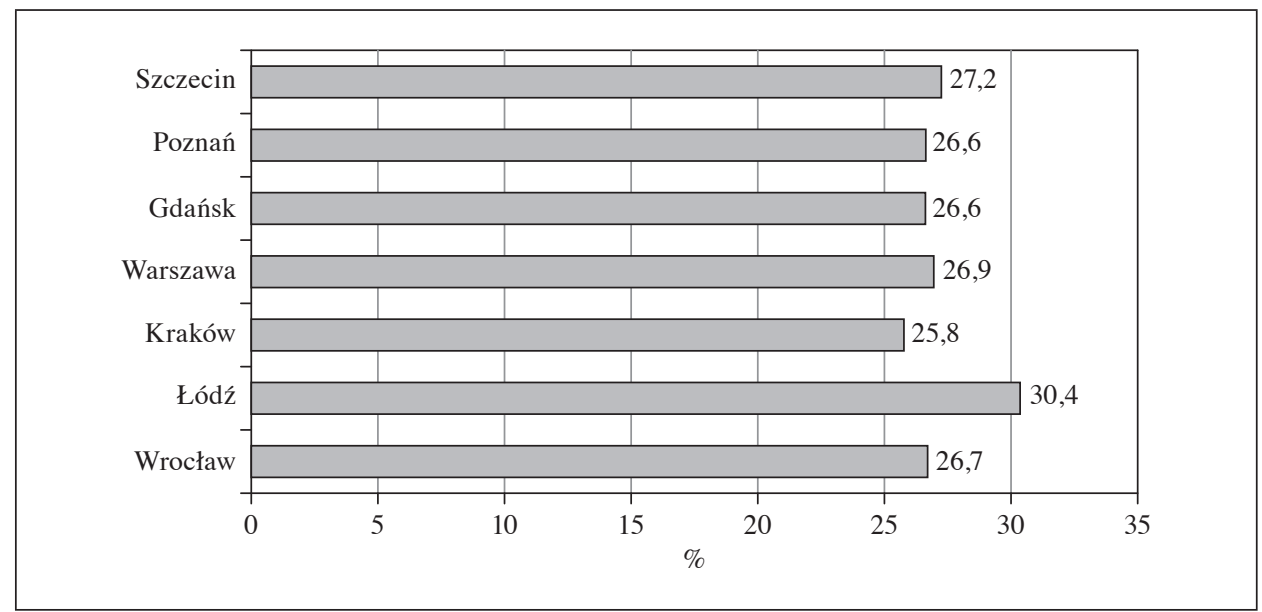

Rys. 3. Udział ludności w wieku 60 lat i więcej w miastach liczących powyżej 400 tys. mieszkańców w Polsce w 2016 r.

Źródło: opracowanie własne na podstawie: Bank Danych Lokalnych, GUS, www.stat.gov.pl/bdl (data dostępu: 18.03.2017).

Podstawowym kryterium wyboru miast do analizy był zbliżony profil demograficzny. Chodziło o dokonanie wyboru dużych miast, które mogą być ze sobą pod tym względem porównywane. Wybrane miasta: Kraków, Wrocław, Poznań i Gdańsk różnią się między sobą pod względem zarówno ekonomicznym, jak i politycznym, można jednak wskazać dla nich wiele punktów wspólnych 


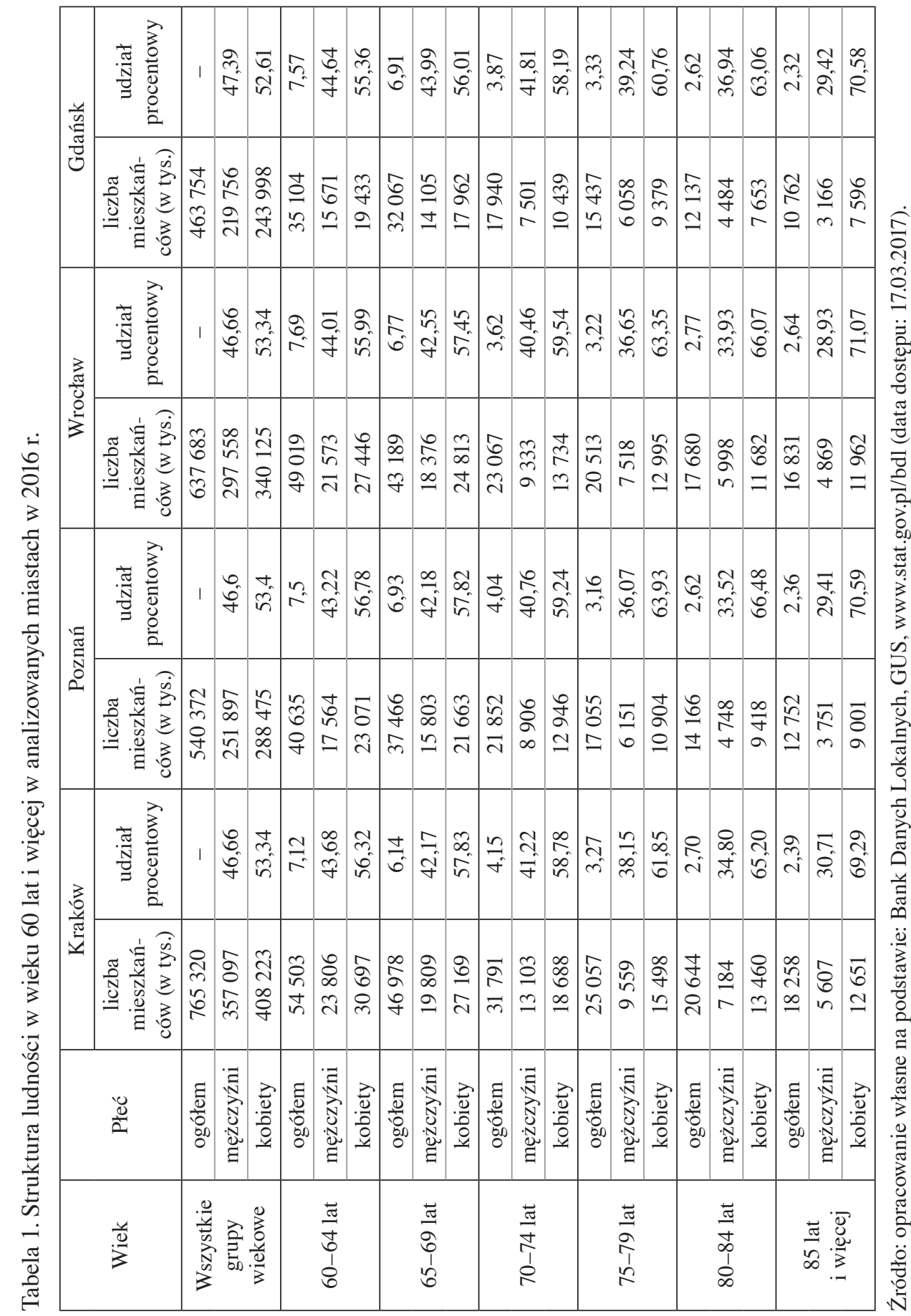


w przebiegu procesów starzenia się ${ }^{2}$ [Kurek 2008, Szukalski 2010]. Powoduje to, że wybór ww. miast do analizy jest najbardziej uzasadniony spośród możliwych opcji. Warszawa ze względu na specyfikę miasta stołecznego została wyłączona $\mathrm{z}$ analiz. W tabeli 1 przedstawiono strukturę ludności grup demograficznych w wieku powyżej 60 lat w wybranych miastach w $2016 \mathrm{r}$.

Dodatkowym kryterium wpływającym na wybór do analizy ww. miast była zbliżona dynamika procesu starzenia się ludności [Kurek 2008, Szukalski 2010], którą odzwierciedlają także prognozy GUS przedstawione w tabeli 2. Widać wyraźnie, że w okresie od 2013 r. (kiedy tworzona była omawiana prognoza) do 2035 r. udział osób w wieku 60 lat i więcej w ogólnej liczbie mieszkańców wybranych miast wzrośnie w szczególności w Gdańsku (według prognoz będzie to różnica 5 pkt proc.). Niewiele mniejszy wzrost odnotowany ma zostać w Poznaniu (4,27 pkt proc.), Krakowie (4,4 pkt proc.) i we Wrocławiu (3,81 pkt proc.). W liczbach bezwzględnych różnice te są bardziej wyraźne, co zaprezentowano w tabeli 3 (wykorzystano dane z 2013 r. jako punkt wyjścia tworzonej wówczas prognozy dla 2035 r.; dane zawarte w tabeli 1 wskazują, że wartości prognozowane w niektórych miastach zostały osiągnięte już w 2016 r.).

W analizie procesów starzenia się ludności miejskiej istotne znaczenie ma uwzględnienie procesu „feminizacji starości” związanego z faktem, że kobiety żyją dłużej i częściej niż mężczyźni dożywają okresu starości. Biorąc pod uwagę podział ludności w wieku 60 lat i więcej w wybranych czterech miastach, należy podkreślić, że udział kobiet w 2016 r. tej populacji we wszystkich miastach jest zbliżony i wynosi, odpowiednio, dla Krakowa 59,9\%, Wrocławia 60,3\%, Poznania $60,4 \%$, a dla Gdańska 58,7\%. Warto zaznaczyć, że przewaga liczby kobiet zaczyna być szczególnie wyraźna w starszych grupach wieku. W grupie osób w wieku 80-84 lat udział kobiet dla Krakowa wynosi $65,2 \%$, Poznania 66,5\%, Wrocławia $66,1 \%$ i dla Gdańska 63,1\%. W najstarszej grupie ludności, w wieku 85 lat i więcej, udział kobiet jest jeszcze wyższy i wynosi: 70,6\% dla Gdańska i Poznania, 69,3\% dla Krakowa i 71,1\% dla Wrocławia. Należy także zwrócić uwagę, że w związku z dłuższym życiem kobiet zjawisko „feminizacji starości” połączone jest również $\mathrm{z}$ singularyzacją, czyli pozostawaniem w jednoosobowym gospodarstwie domowym, co ma konsekwencje nie tylko w wymiarze społecznym, ale i ekonomicznym.

Podobieństwo struktury demograficznej wybranych miast obrazuje także rys. 4. We wszystkich miastach najliczniejszą grupę wśród starszej populacji mieszkańców stanowią osoby w wieku 60-64 lat. Warto zauważyć, że w Krakowie udział tej grupy wieku w ogólnej liczbie ludności jest nieco niższy niż w pozostałych miastach i wynosi $7,1 \%$, podczas gdy dla Wrocławia jest to $7,7 \%$,

2 Por. [Kurek 2008, s. 103], typ B prezentowanej przez autora typologii. 


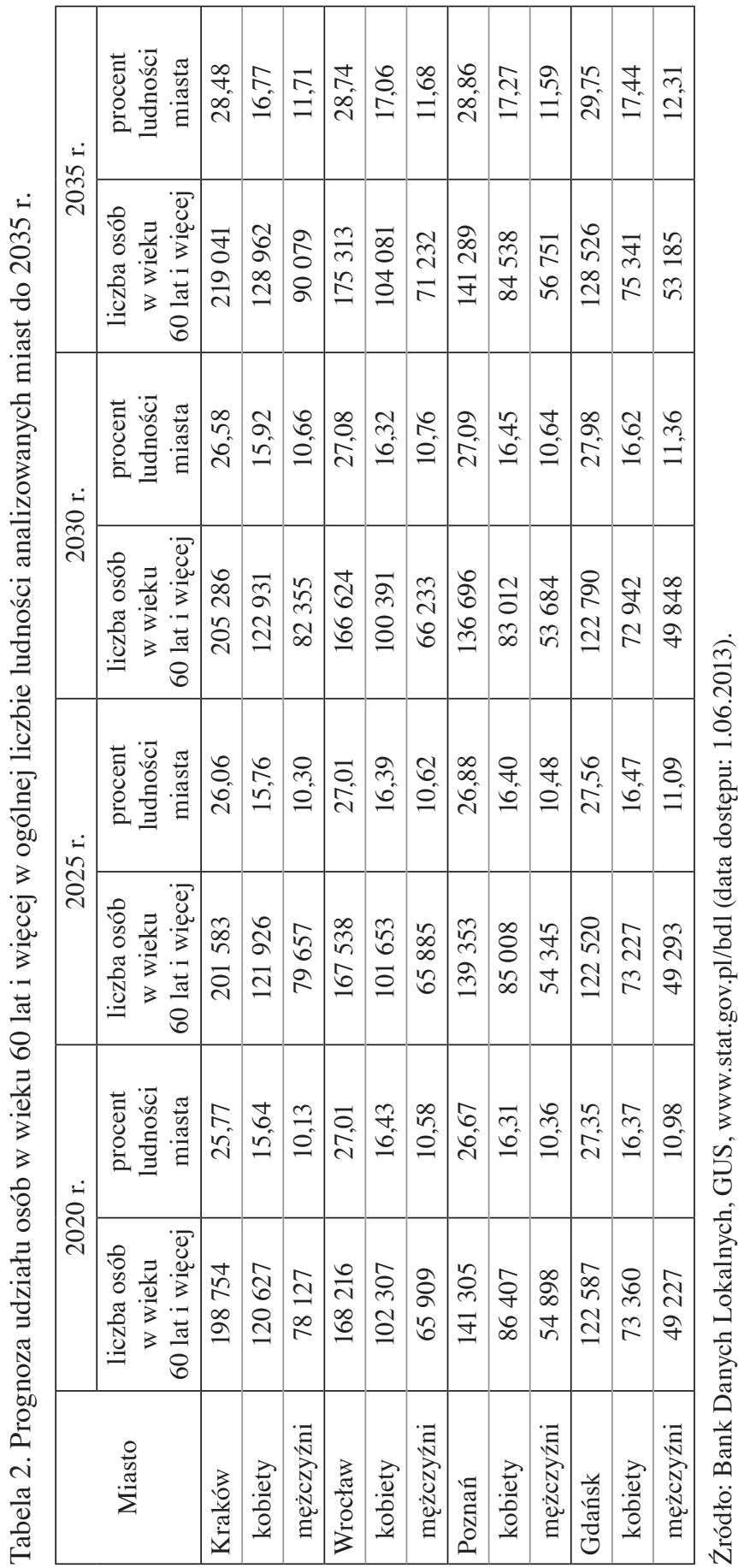


Poznania 7,5\%, a dla Gdańska 7,6\%. W przypadku pozostałych grup wieku sytuacja w wybranych miastach jest zbliżona.

Tabela 3. Liczba ludności w analizowanych miastach według stanu w 2013 r. i prognozy demograficznej na $2035 \mathrm{r}$.

\begin{tabular}{|c|c|c|c|c|}
\hline Wyszczególnienie & Kraków & Wrocław & Poznań & Gdańsk \\
\hline \multicolumn{5}{|c|}{2013} \\
\hline Liczba mieszkańców (w tys.) & 182751 & 157597 & 134778 & 114245 \\
\hline Udział (w \%) & 24,08 & 24,93 & 24,59 & 24,75 \\
\hline \multicolumn{5}{|c|}{2035} \\
\hline Liczba mieszkańców (w tys.) & 219041 & 175313 & 141289 & 128526 \\
\hline Udział (w \%) & 28,48 & 28,74 & 28,86 & 29,75 \\
\hline
\end{tabular}

Źródło: opracowanie własne na podstawie: Bank Danych Lokalnych, GUS, www.stat.gov.pl/bdl (data dostępu: 18.11.2013).

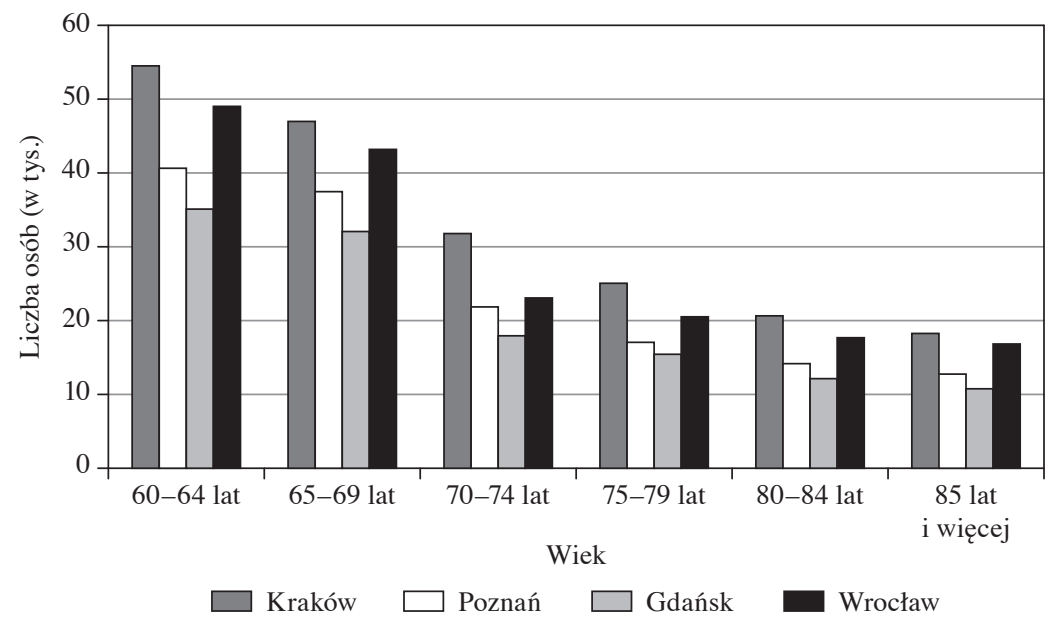

Rys. 4. Liczba osób w wieku 60 lat i więcej w analizowanych miastach w 2016 r.

Źródło: opracowanie własne na podstawie: Bank Danych Lokalnych, GUS, www.stat.gov.pl/bdl (data dostępu: 18.03.2017).

Analizując proces starzenia się polskich miast, warto odwołać się także do popularnego wskaźnika obciążenia demograficznego. Jest to współczynnik, który wyraża stosunek liczby osób w wieku nieprodukcyjnym (przedprodukcyjnym i poprodukcyjnym) do liczby osób w wieku produkcyjnym. Stanowi więc dobrą ilustrację wpływu procesów demograficznych na zasoby pracy. Zmiany jego 
wartości dla wybranych do analizy miast na tle wartości dla Polski ogółem oraz w podziale na miasto i wieś przedstawiono na rys. 5. Aby lepiej zobrazować dynamikę procesu starzenia się, zwłaszcza populacji miejskiej, zdecydowano się na zestawienie wartości współczynnika obciążenia demograficznego dla trzech punktów czasowych: 2010, 2013 i 2016 r.

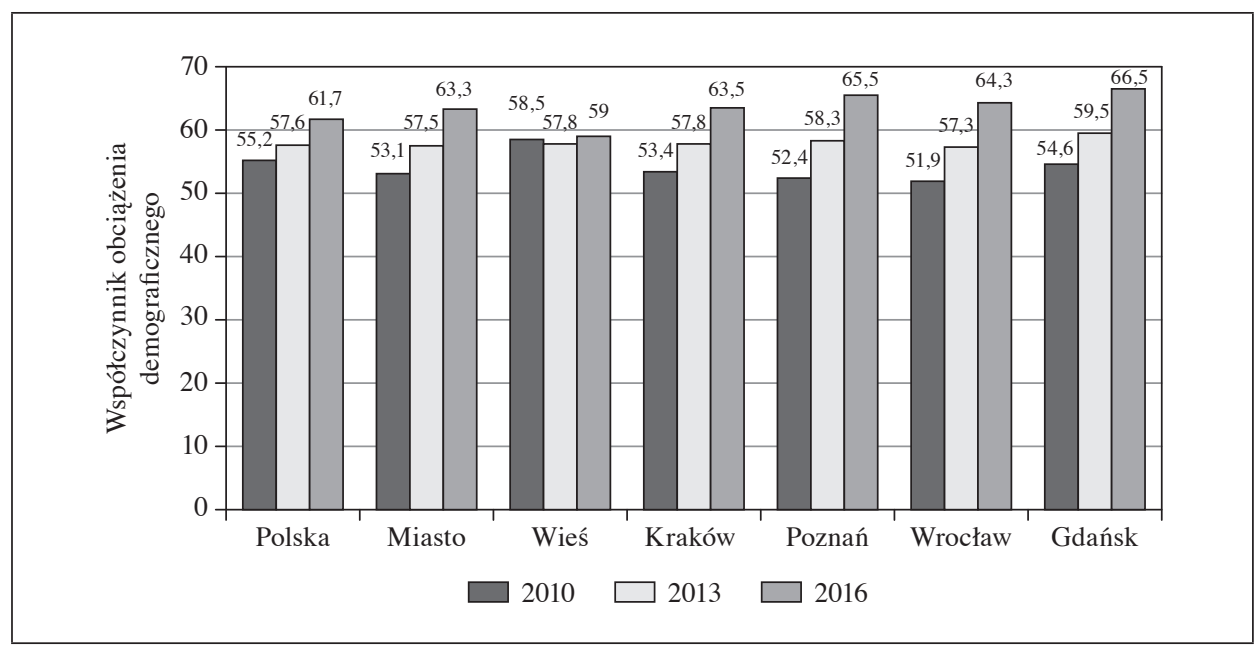

Rys. 5. Współczynnik obciążenia demograficznego w latach 2010, 2013 i 2016

Źródło: opracowanie własne na podstawie: Bank Danych Lokalnych, GUS, www.stat.gov.pl/bdl (data dostępu: 18.03.2017).

W ciągu sześciu lat, między 2010 a 2016 r., widać wyraźną zmianę wartości współczynnika obciążenia demograficznego na obszarach miejskich. W związku z malejącym przyrostem naturalnym i wydłużającym się trwaniem życia wartości tego współczynnika w kolejnych latach zwiększały się i w 2016 r. osiągnął on wartość 63,3. Warto zwrócić uwagę, że wartości współczynnika obciążenia demograficznego dla Wrocławia i Krakowa są bardzo zbliżone na przestrzeni lat, co wskazuje, że dynamika procesu starzenia się w tych miastach jest podobna. Dla Krakowa w 2000 r. wartość współczynnika wyniosła 44,18, co oznacza, że na sto osób w wieku produkcyjnym przypadały średnio 44 osoby w wieku nieprodukcyjnym, a dla Wrocławia 44,44. W 2013 r. było to odpowiednio 57,8 i 57,3, a w 2016 r. 63,5 i 64,3. W przypadku Poznania w 2013 r. wartość współczynnika obciążenia demograficznego wyniosła 58,3, w 2016 r. już 65,5, a dla Gdańska była najwyższa, osiągając wartość 66,5 w 2016 r. 
Pewną modyfikacją wskaźnika obciążenia demograficznego ${ }^{3}$ jest wskaźnik wyrażający stosunek liczby osób w wieku poprodukcyjnym do liczby osób w wieku produkcyjnym. Jest to wskaźnik obciążenia ludności w wieku produkcyjnym ludnością w wieku poprodukcyjnym. Jego zmiany przedstawiono na rys. 6 .

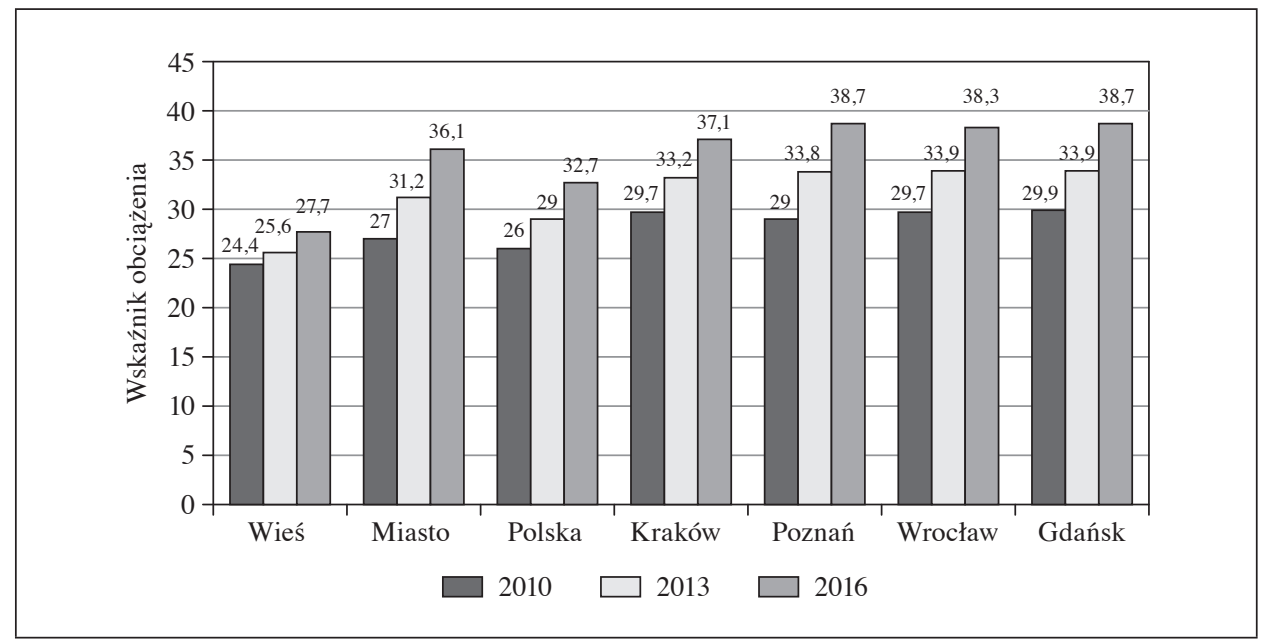

Rys. 6. Wskaźnik obciążenia ludności w wieku produkcyjnym ludnością w wieku poprodukcyjnym w latach 2010, 2013 i 2016

Źródło: opracowanie własne na podstawie: Bank Danych Lokalnych, GUS, www.stat.gov.pl/bdl (data dostępu: 18.03.2017).

Dla analizowanych miast wartość tego wskaźnika jest wyższa od wartości dla Polski - w 2016 r. wyniósł on 32,7, a także od wartości dla terenów miejskich w tym samym roku wyniósł on 36,1 . Dane te wskazują na dynamiczny proces starzenia się wielkich miast Polski.

Można także wyliczyć współczynnik obciążenia emerytami, czyli stosunek osób pobierających świadczenia emerytalne do ludności pracującej. Według danych GUS [Karczewicz 2013] w marcu $2013 \mathrm{r}$. emeryturę pobierało 4,97 $\mathrm{mln}$ osób. W tym czasie 15,57 mln osób można było zakwalifikować do grupy ludności pracującej [Zgierska 2014]. Oznacza to, że wartość współczynnika obciążenia emerytami wynosiła 31,9 , czyli na 100 osób w wieku produkcyjnym przypadały prawie 32 osoby pobierające świadczenia emerytalne. Według ONZ, aby utrzymać bieżące współczynniki obciążenia emerytami ludności pracującej, wymagany poziom natężenia imigracji do krajów wysoko rozwiniętych spowodowałby,

${ }^{3}$ Por. przegląd miar stosowanych do analizy procesu starzenia się przedstawiony przez W. Wolańską [2013]. 
że w 2050 r. udział imigrantów w tych krajach wynosiłby przynajmniej 59\% (za: [Kurek 2008, s. 23]). Dane te bardzo wyraźnie obrazują przemiany demograficzne na rynku pracy. Warto podkreślić, że wskaźnik ten uwzględnia liczbę ludności pracującej, w której mogą znaleźć się także osoby jednocześnie pobierające świadczenia emerytalne i podejmujące działalność zarobkową.

W analizie przemian demograficznych można wykorzystać również indeks starości, który wyraża stosunek ludności starej (w wieku 65 lat i więcej) do ludności młodej (0-14 lat). Zmiany tej miary w przypadku analizowanych miast na tle jej wartości dla Polski ogółem oraz w podziale na wieś i miasto zaprezentowano na rys. 7.

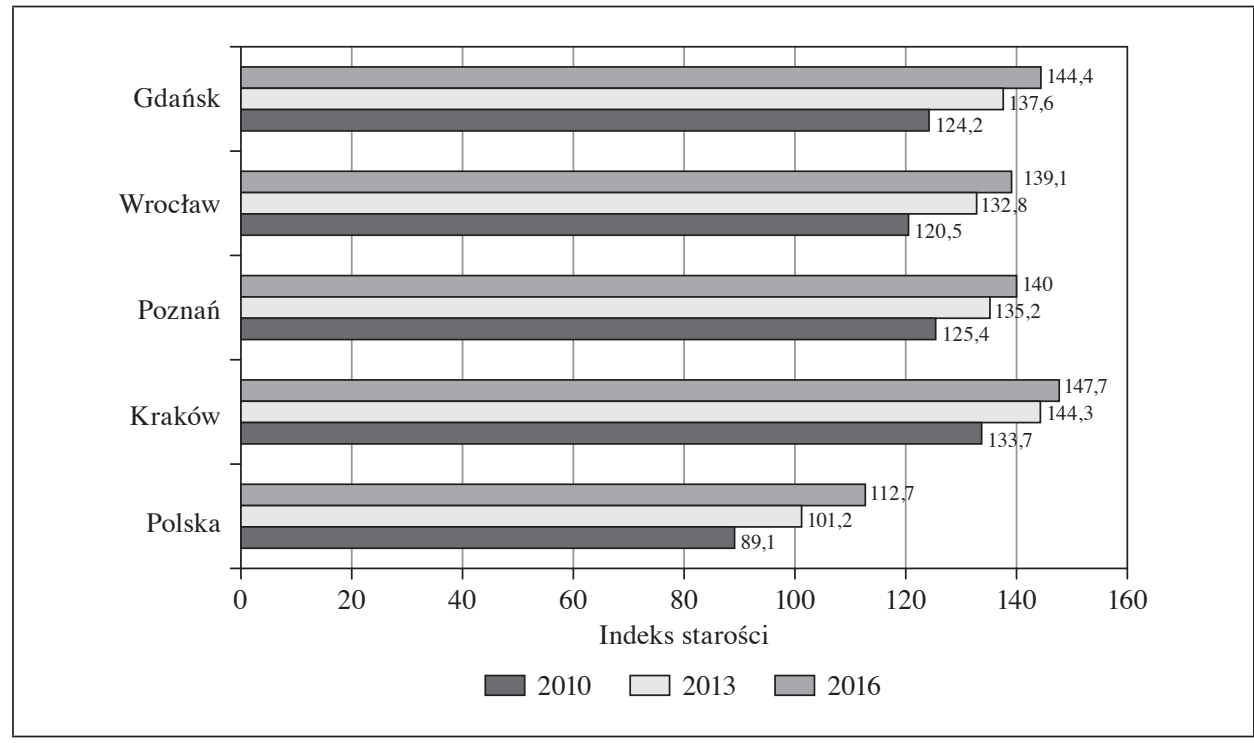

Rys. 7. Indeks starości dla analizowanych miast w latach 2010, 2013 i 2016

Źródło: opracowanie własne na podstawie: Bank Danych Lokalnych, GUS, www.stat.gov.pl/bdl (data dostępu: 18.03.2014).

Porównując sytuację w analizowanych miastach, można zauważyé, że wartości indeksu starości są bardzo zbliżone dla Krakowa i Gdańska, w których na 100 osób młodych w 2013 r. przypadało około 144 osób w wieku 65 lat i więcej. Należy także zwrócić uwagę na zmianę wartości wskaźnika w Polsce - w analizowanym okresie, czyli od 2010 do 2016 r., wartość wskaźnika wzrosła z 89,1 do 112,7. Oznacza to, że w 2016 r. na każde 100 dzieci w wieku 0-14 lat przypadało o ponad 23 osoby starsze więcej niż w $2010 \mathrm{r}$.

Na proces starzenia się populacji wpływ ma także naturalny ruch ludności mierzony przez przyrost naturalny, który wyraża różnicę w poziomie urodzeń 
żywych i zgonów. Jego wartości w latach 2002, 2013 i 2016 dla analizowanych miast przedstawiono na rys. 8 .

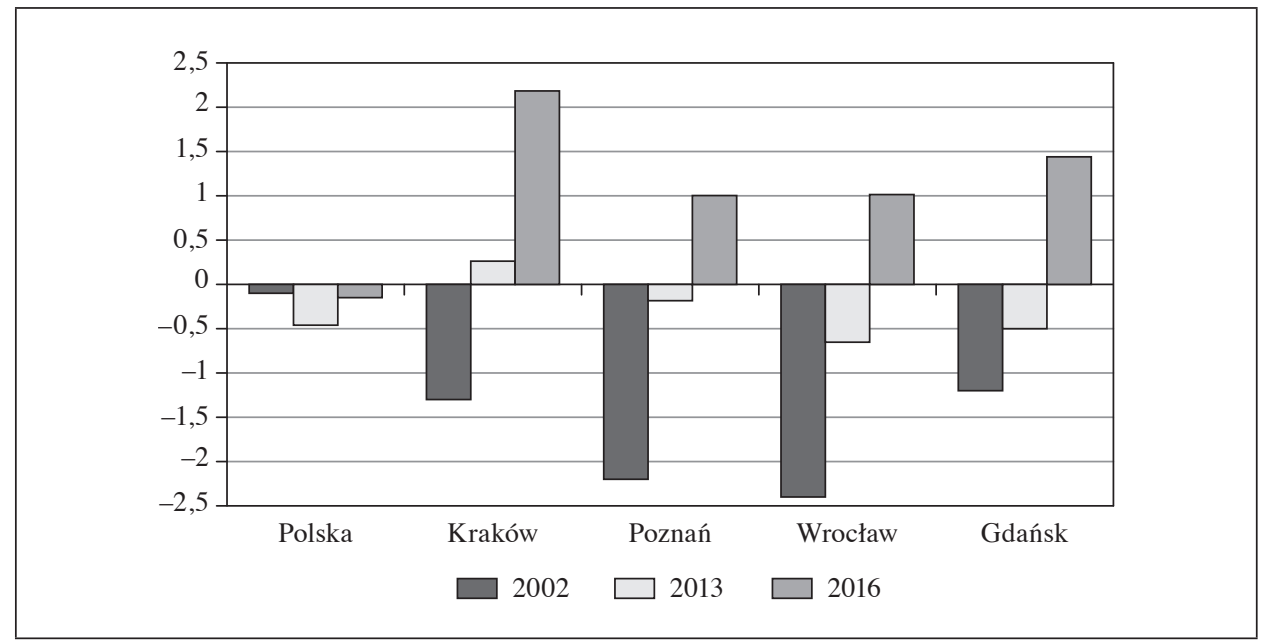

Rys. 8. Przyrost naturalny na 1000 osób w analizowanych miastach w latach 2002, 2013 i 2016

Źródło: opracowanie własne na podstawie: Bank Danych Lokalnych, GUS, www.stat.gov.pl/bdl (data dostępu: 18.03.2017).

Zaprezentowane dane obrazują ujemny poziom przyrostu naturalnego w 2013 r. we wszystkich analizowanych miastach z wyjątkiem Krakowa. Ujemne wartości przyrostu naturalnego świadczą o malejącej liczbie urodzeń, która wiąże się z niżem demograficznym. W 2016 r. można zaobserwować dodatnie wartości przyrostu naturalnego we wszystkich analizowanych miastach. Na szczególną uwagę zasługuje jego wyższa niż w pozostałych miastach wartość w Krakowie.

Miarami uzupełniającymi informacje, jakie niesie ze sobą wskaźnik przyrostu naturalnego, są współczynnik dzietności i współczynnik reprodukcji brutto, które dostarczają informacji na temat wzorów prokreacyjnych w danej populacji. Wartości obu współczynników przedstawiono na rys. 9 i $10^{4}$.

Przedstawione na rys. 9 i 10 dane wskazują na niski poziom urodzeń oraz na poziom reprodukcji, który nie gwarantuje prostej zastępowalności pokoleń, co wiązać można przede wszystkim ze zmianami kulturowymi i obyczajowymi. Wśród analizowanych miast zbliżoną wartość współczynnika dzietności w $2016 \mathrm{r}$. odnotowano dla Poznania - 1,35 i Krakowa - 1,32, podczas gdy dla Wrocławia wartość ta wyniosła 1,28 . W przypadku reprodukcji brutto najniższą wartość

${ }^{4}$ Ze względu na brak dostępności danych w analizach nie uwzględniono Gdańska. 
odnotowano w 2016 r. dla Wrocławia - 0,62, nieco wyższą dla Krakowa - 0,65, a dla Poznania 0,654. Warto także podkreślić, że pomimo iż wartości obu współczynników są niskie, to i tak wzrosły w porównaniu z 2013 r.

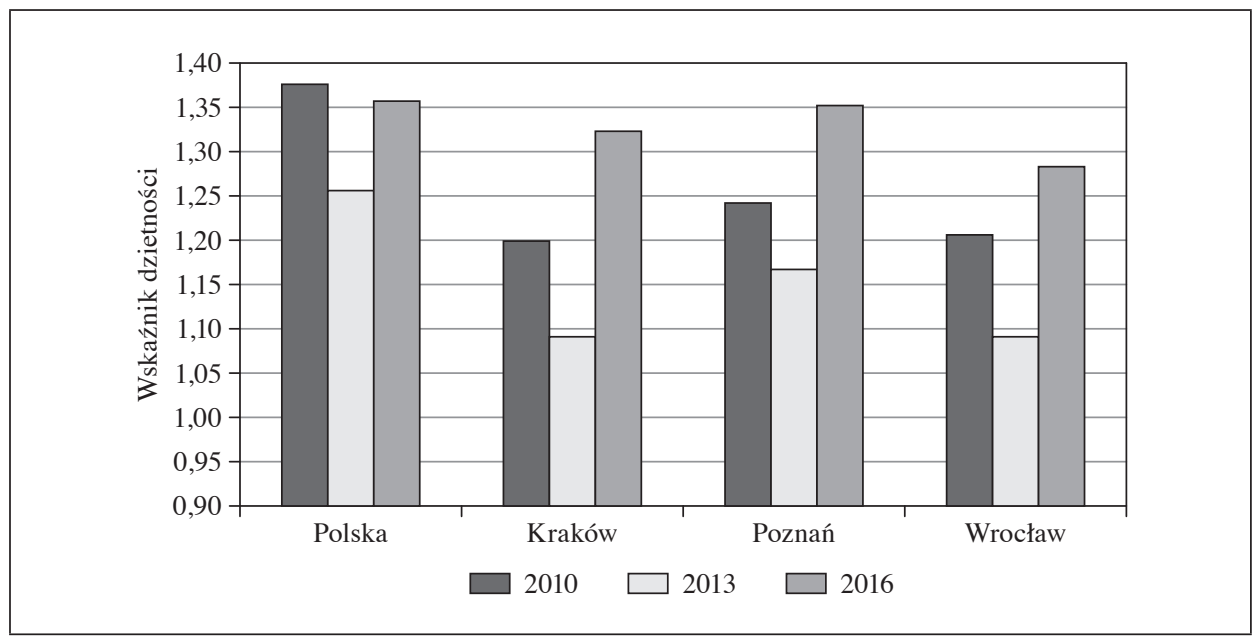

Rys. 9. Wskaźnik dzietności dla Krakowa, Poznania i Wrocławia w latach 2010, 2013 i 2016 Źródło: opracowanie własne na podstawie: Bank Danych Lokalnych, GUS, www.stat.gov.pl/bdl (data dostępu: 18.03.2017).

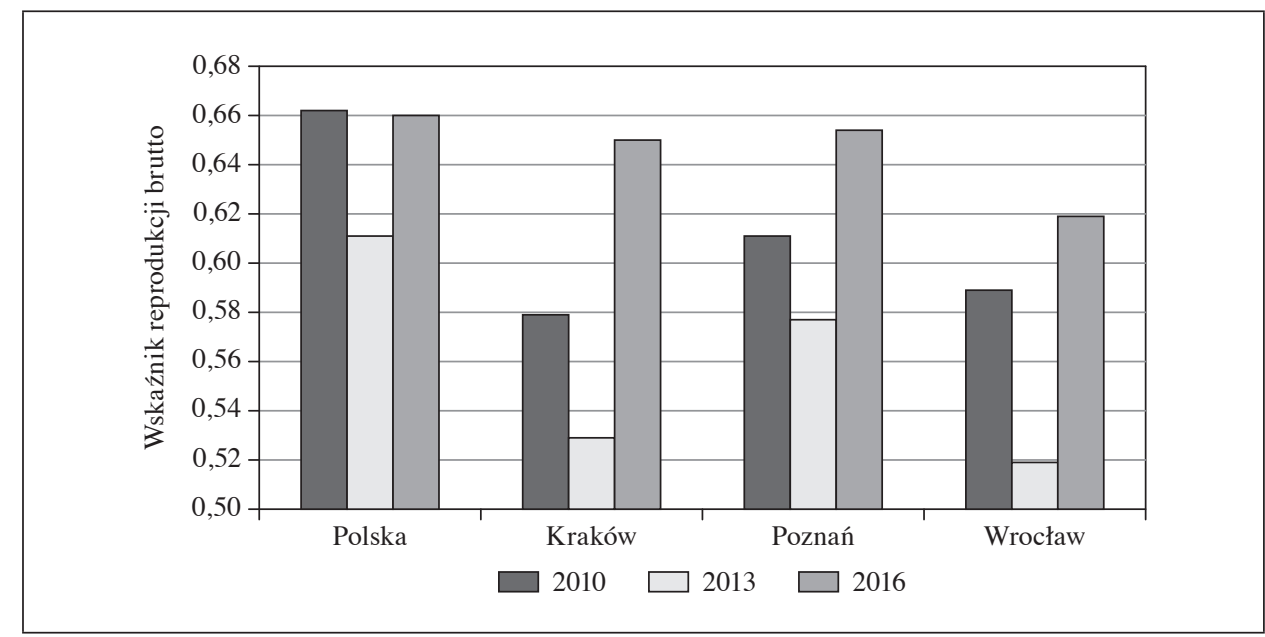

Rys. 10. Wskaźnik reprodukcji brutto dla Krakowa, Poznania i Wrocławia w latach 2010, 2013 i 2016

Źródło: opracowanie własne na podstawie: Bank Danych Lokalnych, GUS, www.stat.gov.pl/bdl (data dostępu: 18.03.2017). 
Aby obraz zmian liczby mieszkańców na danym obszarze był kompletny, oprócz wskaźnika przyrostu naturalnego należy wykorzystać także saldo migracji. Jego wartości dla Polski ogółem i w podziale na obszary miejskie i wiejskie w latach 1995, 2002 i 2013 zaprezentowano na rys. 115. Uzupełnieniem tego wskaźnika jest sumaryczna stopa salda migracji. Jest to współczynnik salda migracji w ciągu roku; wartość wyrażana jest na 1000 mieszkańców. Sumaryczną stopę salda migracji na 1000 osób w analizowanych miastach przedstawiono na rys. 12 .

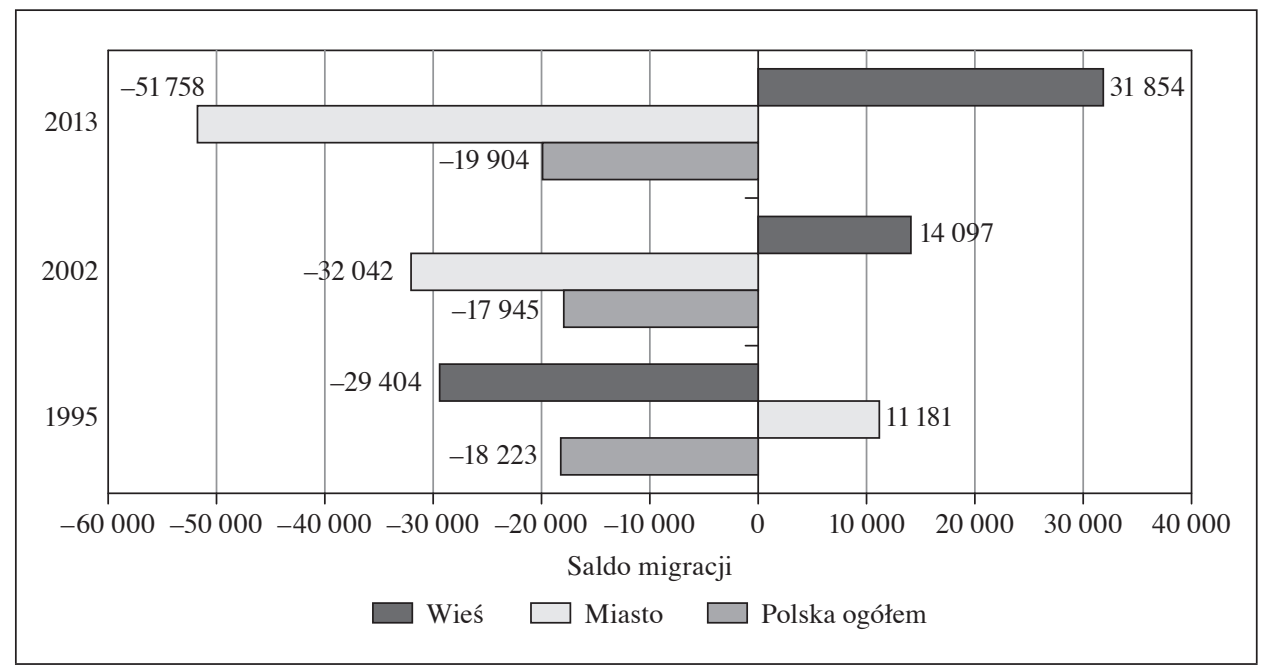

Rys. 11. Saldo migracji w Polsce w latach 1995, 2002 i 2013

Źródło: opracowanie własne na podstawie: Bank Danych Lokalnych, GUS, www.stat.gov.pl/bdl (data dostępu: 18.07.2016).

Saldo migracji dla Polski ogółem ma ujemne wartości dla wszystkich analizowanych lat. Wskazuje to na większą liczbę osób opuszczających kraj niż imigrantów. Porównując wartości salda migracji z terenów wiejskich z wartościami salda migracji z terenów miejskich, należy zauważyć zmianę kierunku migracji. O ile w latach 90 . XX w. dominował kierunek migracji do miasta, o tyle w kolejnych latach dodatnie saldo migracji odnotowywane jest na obszarach wiejskich. Jest to odzwierciedleniem trendu „kurczenia się miast” i coraz bardziej wyraźnego wpływu zjawiska suburbanizacji. Coraz większa część ludności miejskiej decyduje się na przeprowadzkę na peryferia. Na podjęcie takiej decyzji ma wpływ wiele czynników, w tym rozwój elastycznych form zatrudnienia, coraz lepsza jakość infrastruktury czy obniżający się poziom zadowolenia z jakości

${ }^{5} \mathrm{~W}$ analizach nie uwzględniono 2016 r. ze względu na brak dostępności danych. 
życia w miastach. Proces „rozlewania się miast”, czyli tworzenia dużych obszarów o mniej gęstej zabudowie w rejonach oddalonych od centrum, ale z rozwiniętą siecią miejskiej komunikacji, ma poważne konsekwencje dla zasobów kapitału ludzkiego w miastach. Najczęściej na wyprowadzkę decydują się bowiem osoby w sile wieku, przedsiębiorcze i na ogół lepiej wykształcone [Sagan 2013, s. 76].

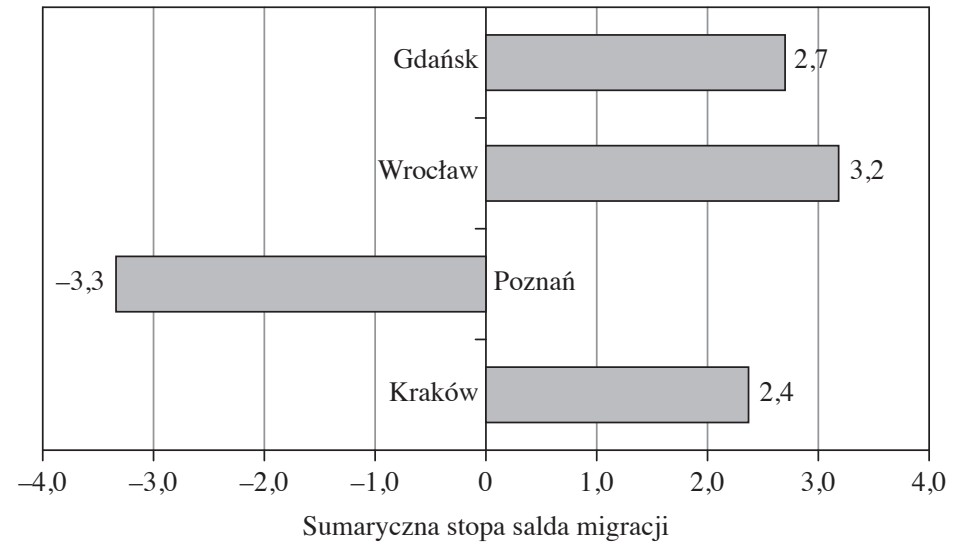

Rys. 12. Sumaryczna stopa salda migracji na 1000 osób w analizowanych miastach w 2016 r.

Źródło: opracowanie własne na podstawie: Bank Danych Lokalnych, GUS, www.stat.gov.pl/bdl (data dostępu: 18.03.2017).

Analizując dane dla wybranych miast, należy zwrócić uwagę na odwrotną do typowej w skali całego kraju tendencję występującą w Gdańsku, we Wrocławiu i w Krakowie, dla których sumaryczna stopa salda migracji w 2016 r. miała wartości dodatnie. Ujemne wartości dla Poznania wskazują na większą liczbę opuszczających to miasto niż decydujących się na zamieszkanie w nim. Tłumaczyć można to intensywnym rozwojem aglomeracji poznańskiej tworzonej przez miasto Poznań i powiat poznański (por. [Mieszkańcy Poznania 2014]).

Innym bardzo istotnym wskaźnikiem obrazującym proces starzenia się populacji, którego wartość systematycznie wzrasta, jest przeciętne dalsze trwanie życia. Na rys. 13 zaprezentowano wartości tego wskaźnika dla kobiet i mężczyzn w Polsce w latach 2000 i $2015^{6}$.

Jak można zauważyć, przeciętne dalsze trwanie życia systematycznie się wydłuża. Dla kobiet urodzonych w 2015 r. wynosi 81 lat, a dla mężczyzn 73,6

${ }^{6} \mathrm{~W}$ analizach nie uwzględniono 2016 r. ze względu na brak dostępności danych. 
roku. W przypadku analizowanych miast w 2015 r. Kraków osiągnął najwyższe wartości przeciętnego dalszego trwania życia zarówno dla kobiet - 82,6 roku, jak i dla mężczyzn - 76,3 roku. W Poznaniu i we Wrocławiu przeciętne dalsze trwanie życia dla noworodków płci męskiej w 2015 r. wyniosło tyle samo, tj. 75,1 roku, a dla kobiet odpowiednio: 81,3 roku w Poznaniu i 81,5 roku we Wrocławiu. Warto zauważyć, że w przypadku wszystkich miast przeciętne dalsze trwanie życia osób w wieku poprodukcyjnym również było zbliżone i wynosiło dla kobiet około 24 lata, a dla mężczyzn około 20 lat $^{7}$.

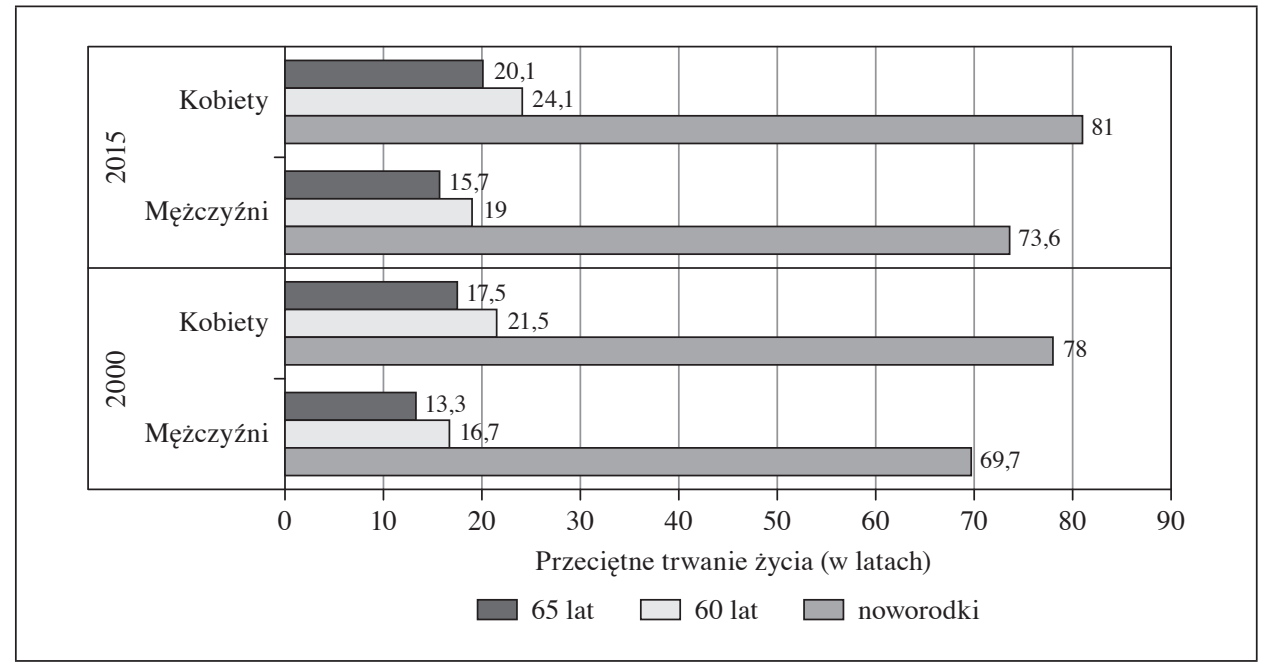

Rys. 13. Przeciętne trwanie życia w Polsce dla noworodków oraz kobiet i mężczyzn w wieku 60 i 65 lat w 2000 i 2015 r.

Źródło: opracowanie własne na podstawie: Bank Danych Lokalnych, GUS, www.stat.gov.pl/bdl (data dostępu: 18.03.2017).

Należy podkreślić, że przeciętne dalsze trwanie życia nie jest wskaźnikiem tak użytecznym jak wskaźnik przeciętnego trwania życia w zdrowiu, który wzbogaca wskaźnik dalszego trwania życia o wymiar jakościowy. Zawiera bowiem informację o średnim trwaniu życia bez niepełnosprawności. Zgodnie z danymi Eurostatu w Polsce w 2012 r. przeciętne dalsze trwanie życia bez niepełnosprawności wynosiło 59,2 roku dla mężczyzn i 62,9 roku dla kobiet. W przypadku mężczyzn była to wartość niższa od średniej europejskiej, która wynosiła 61,3 roku, a w przypadku kobiet była to wartość wyższa od średniej europejskiej dokładnie o rok. Warto także zwrócic uwagę, że Polska ma zdecydowanie niższe

${ }^{7}$ Ze względu na brak dostępności danych we wskazanych okresach w analizach nie uwzględniono Gdańska. 
wskaźniki dalszego trwania życia w zdrowiu dla osób w wieku 65 lat. Dla kobiet jest to 7,8 roku, a dla mężczyzn 7,4 roku.

Analizując dane dla krajów europejskich, można wskazać grupę państw, takich jak Norwegia, Szwecja, Islandia i Szwajcaria, w których zarówno kobieta, jak i mężczyzna w wieku 65 lat będzie żyć w zdrowiu przynajmniej 10 lat. Natomiast w przypadku takich krajów, jak Słowacja, Rumunia, Estonia, Litwa, Węgry i Łotwa dla mężczyzn i kobiet w wieku 65 lat przeciętne trwanie życia w zdrowiu jest mniejsze niż 6,5 roku. Różnice te wynikają nie tylko z kondycji systemu opieki zdrowotnej, ale przede wszystkim ze stylu życia, którego konsekwencje odzwierciedlają się w ostatnich latach życia. Wysokie spożycie alkoholu i wyrobów tytoniowych oraz niedbanie o kondycję fizyczną to główne czynniki, które wpływają na niskie wartości wskaźnika przeciętnego dalszego trwania życia w zdrowiu.

\section{Wnioski}

Proces starzenia się polskich miast jest złożony i warunkowany przez współwystępowanie różnych czynników. Prognozy demograficzne wskazują, że w ciągu najbliższych lat polskie miasta będą się zmieniać. Malejąca liczba urodzeń i ruchy migracyjne powodować będą z jednej strony „kurczenie się miast”, z drugiej zaś zmiany w sektorze zatrudnienia i rozwój infrastruktury przyczyniać się będą do „rozlewania się miast”. W efekcie miasto będzie stawać się środowiskiem życia, w którym osoby starsze będą stanowić coraz liczniejszą grupę mieszkańców. W związku z tym konieczne będzie dostosowywanie narzędzi miejskiej polityki senioralnej w taki sposób, aby zaspokoić potrzeby tej grupy.

\section{Literatura}

Artysiewicz I. [1977], Ludzie starzy w województwie białostockim, „Wiadomości Statystyczne GUS-PTS", nr 12.

Bielecka B. [1976], Zmiany w ruchu naturalnym i strukturze wieku ludności województwa kieleckiego, „Prace i Studia Instytutu Geografii UW”, nr 19.

Długosz Z., Kurek S. [1997], Aging of the Populations of Large Polish Cities versus Age Patterns in Other Settlement Units, „Studia i Materiały”, nr 4.

Długosz Z., Kurek S. [2005], Starzenie się ludności w Polsce na tle regionów Unii Europejskiej, „Konspekt”, nr 4(24).

Długosz Z., Rachwał T. [1998], Poziom i dynamika starzenia się ludności w województwie krakowskim w latach 1988-96 w świetle wybranych struktur demograficznych, „Rocznik Naukowo-Dydaktyczny WSP w Krakowie”, nr 198. 
Frąckiewicz L. [2004], Starzy ludzie w miastach ślqskich [w:] Przemiany demograficzne i jakość życia ludności miast, red. J. Słodczyk, D. Rajchel, Wydawnictwo Uniwersytetu Opolskiego, Opole.

Gawryszewski A. [2005], Ludność Polski w XX wieku, PAN, Warszawa.

Gordecka B. [1980], Starzenie się i starość demograficzna ludności województwa opolskiego w latach 1950-1977, „Studia Śląskie”, nr 37.

Grzelak-Kostulska E. [2001], Przemiany w strukturach i procesach demograficznych na obszarze województwa kujawsko-pomorskiego, UMK, Toruń.

Karczewicz E. [2013], Struktura wysokości emerytur i rent wypłacanych przez ZUS po waloryzacji w marcu 2013 roku, GUS, Warszawa, http://www.zus.pl/files/Struktura $\% 20$ wysoko\%C5\%9Bci\%20emerytur\%20i\%20rent $\% 20$ wyp $\%$ C5\%82acanych $\% 20$ przez\%20ZUS\%20po\%20waloryzacji\%20w\%20marcu\%202013\%20r.pdf (data dostępu: 18.03.2017).

Katsarova I. [2008], Regiony wyludniajace się: nowy paradygmat demograficzny i terytorialny. Studium, Parlament Europejski, Bruksela, http://www.europarl. europa.eu/ RegData/etudes/etudes/join/2008/408928/IPOL-REGI_ET\%282008\%29408928\% 28SUM01\%29_PL.pdf (data dostępu: 18.03.2017).

Klimczuk A. [2012], Kapitał społeczny ludzi starych na przykładzie mieszkańców miasta Białystok, Wiedza i Edukacja, Lublin.

Kurek S. [2008], Typologia starzenia się ludności Polski w ujęciu przestrzennym, Wydawnictwo Naukowe Akademii Pedagogicznej, Kraków.

Labus A. [2013], Odnowa miast w kontekście starzenia się społeczeństwa na przykładzie wybranych miast europejskich XXI wieku, ,Acta Universitatis Lodziensis. Folia Oeconomica", nr 297.

Mieszkańcy Poznania, raport, http://www.poznan.pl/mim/s8a/attachments.html?co=showiinstance $=1011$ iparent=43919ilang $=$ pliid=91226 (data dostępu: 7.05.2014).

Niekrasz J.A. [1980], Proces starzenia się ludności na Pomorzu środkowym, „Koszalińskie Studia i Materiały", nr 3.

Obraniak W. [1992], Struktura demograficzna ludności dużych i wielkich miast w Polsce, „Prace Instytutu Ekonometrii i Statystyki UŁ”, nr 98.

Obraniak W. [2006], Struktura demograficzna i społeczno-ekonomiczna ludzi starych $w$ wielkich miastach $w$ Polsce w świetle spisów ludności z lat 1988 i 2002 [w:] Ludzie starzy w polskim społeczeństwie w pierwszych dekadach XXI wieku, red. J.T. Kowalewski, Wydawnictwo Uniwersytetu Łódzkiego, Łódź.

Prognoza ludności Polski na lata 2003-2030 [2004], GUS, www.stat.gov.pl/cps/rde/xbcr/ gus/PUBL_prognoza_ludnosci_1_polska.xls (data dostępu: 18.03.2017).

Prognoza ludności na lata 2008-2035 [2009], GUS, http://stat.gov.pl/cps/rde/xbcr/gus/L_ prognoza_ludnosci_na_lata2008_2035.pdf (data dostępu: 18.03.2017).

Sagan I. [2013], Wykład wprowadzający [w:] Zarzqdzanie rozwojem miast o zmniejszajqcej się liczbie mieszkańców (w kontekście perspektywy finansowej 2014-2020), Kancelaria Senatu, Warszawa, http://senat.gov.pl/gfx/senat/userfiles/_public/k8/agenda/ seminaria/2013/130301/zarzadzanie_rozw_mias.pdf (data dostępu: 18.03.2017).

Szukalski P. [2009], Starzenie się ludności - wyzwanie XXI wieku [w:] Przygotowanie do starości. Polacy wobec starzenia się, red. P. Szukalski, Instytut Spraw Publicznych Warszawa.

Szukalski P. [2010], Starzenie się ludności Łodzi na tle największych polskich miast od poczqtku XX wieku, ,Acta Universitatis Lodziensis. Folia Sociologica”, nr 35. 
Wierzchosławski S. [1999], Demograficzne aspekty procesu starzenia się ludności Polski, „Ruch Prawniczy Ekonomiczny i Socjologiczny", nr 1.

Wnuk W., Machaj Z., Orzechowska G., Pierzchalska A., Pisarczyk-Bogacka E., Bogowolska-Wepsięć M., Klakocaar J. [2008], Kondycja życiowa Dolnoślqaskich seniorów, DOPS, Wrocław.

Wolańska W. [2013], Przestrzenne zróżnicowanie starzenia się ludności Polski w latach 1995-2035, „Acta Universitatis Lodziensis. Folia Oeconomica”, nr 291.

Zgierska A. [2014], Aktywność ekonomiczna ludności Polski w I kwartale 2013 roku, GUS, Warszawa.

\section{Aging in an Urban Environment in Poland at the Beginning of the Twenty- -First Century - Demographics and Social Aspects}

(Abstract)

The article presents the basic principles of sociological analysis of the urban environment in the context of population aging in the city. It discusses the main concepts developed in social gerontology and presents the social perspective on an aging urban population. It presents the main demographic trends observed today in Poland's cities by describing a number of indicators used in the analysis of the aging population. Conclusions resulting from the analysis show that the decreasing number of births and migration will result in shrinking cities. On the other hand, changes in the employment sector and infrastructure development will contribute to urban sprawl. As a result, the elderly will constitute a growing group in cities.

Keywords: aging, social gerontology, city, sociology of old age. 